\title{
STUDY OF ABIOTIC FACTORS ACROSS THE BRAHMAPUTRA BELT IN RELATION TO ITS SUITABILITY FOR AQUATIC LIFE
}

\author{
Chandasudha Goswami ${ }^{1}$, V. S. Zade ${ }^{2}$ \\ ${ }^{1}$ Research Scholar, Dept. of Zoology, Govt. Institute of Science \& Humanities, Amravati \\ ${ }^{2}$ Associate Prof. of Govt. Institute of Science \& Humanities, Amravati
}

\begin{abstract}
A healthy ecosystem is a result of balanced interaction between biotic and abiotic factors. Water temperature, pH, DO, FCO2, TA, TH etc are the most important abiotic factors influencing the physico-chemical and biological events of water body (Rahman et al., 2008). All species have their own optimal range for these abiotic parameters. In relation to aquatic life, there maturation time is also dependent on these parameters. These factors have great influence on aquatic life (DuttaMunshi and DuttaMunshi, 1995). This paper deals with the observation of fluctuation of these abiotic factors across the Brahmaputra Belt and its relation with aquatic life, mostly fishes.
\end{abstract}

Keywords: Water temperature, $\mathrm{pH}, \mathrm{DO}, \mathrm{FCO} 2, \mathrm{TA}, \mathrm{TH}$ etc...

\section{INTRODUCTION}

Water temperature, pH, DO, FCO2, TA, TH have influential effect on water body as well as aquatic life. Water temperature is one of the most important factors, which influence the physic-chemical and biological events of a water body. $\mathrm{pH}$ affects the metabolism and other physiological processes of aquatic organisms. Among the chemical substances in natural water, oxygen is probably one of primary importance both as a regulator of metabolic processes of plant and animal community and as an indicator of water condition (Banerjea, 1971). Carbon dioxide is a foundation of material for the photosynthesis of aquatic plants. The growth and reproduction of phytoplankton will be restrained in case of lack of Carbon dioxide. However, it will be harmful to fishes if free carbon dioxide content is too high. Alkalinity or acid combining capacity of natural fresh water pond is generally caused by carbonates and bicarbonates of calcium and magnesium, calcium forming the major constituent (Banerjea, 1971). Alkalinity is a measurement of carbonate and bicarbonate ions dissolved in the water. Total hardness means the combined content of alkaline earth metals (Calcium and Magnesium) with weak acid and strong acid. Calcium is the main material for the formation of fish bone and is also one of the essential elements for food organisms, while Magnesium is the main element of chlorophyll needed for all kind of algae.

\section{MATERIALS AND METHODS}

\subsection{Water Temperature:}

Water temperature of both pond and tanks was measured on the spot using a portable water thermometer (in degree Celsius scale).

\section{$2.2 \mathrm{pH}:$}

The $\mathrm{pH}$ or the concentrations of hydrogen ions $(\mathrm{H}+)$ present in water is a measure of acidity and alkalinity. Dissociation of water results in the formation of $\mathrm{H}+$ and $\mathrm{OH}-$ ions. $\mathrm{H}+$ ions are responsible for acidity and $\mathrm{OH}^{-}$ions for basic property.

$$
\mathrm{H} 2 \mathrm{O}=\mathrm{H}++\mathrm{OH}-
$$

It is also the negative logarithm of the concentration of hydrogen ions (DuttaMunshi and DuttaMunshi, 1995). The formula will be as follows:

$$
\begin{gathered}
\mathrm{pH}=\frac{1}{\log 10 \mathrm{H}+\text { ion concentration }} \\
\text { or } \mathrm{H}+=10-\mathrm{pH}
\end{gathered}
$$

The $\mathrm{pH}$ was determined directly with the help of a digital pocket sized pH meter (Model: HI- 96107, HANNA instrument). The instrument was calibrated for each measurement with standard buffer solution having $\mathrm{pH} 7$.

\subsection{Dissolved Oxygen (DO):}

The main sources of dissolved oxygen in water are i) the atmosphere ii) by photosynthetic activity of aquatic plant (DuttaMunshi and DuttaMunshi, 1995). The reaction is as follows:

$$
6 \mathrm{CO} 2+6 \mathrm{H} 2 \mathrm{O}+\text { Sunlight }=\mathrm{C} 6 \mathrm{H} 12 \mathrm{O} 6+6 \mathrm{CO} 2
$$

DO is needed for respiration, it is one of necessary conditions for the life of fish. Water samples are collected from sub surface, about 15 to $20 \mathrm{~cm}$ below the surface level of pond water. To make the sample representative, a 
number of samples were collected from different places and mixed to have the final sample. Water sample was chemically fixed in the field and brought to the laboratory for further processing. The estimation was done by modified Wrinkler's method followed after Trvedi and Goel (1986) and APHA (1989). The method is based on the principle that Oxygen combines with Manganoushydroxide, which on acidification liberates Iodine equivalent to that of Oxygen fixed. The Iodine is titrated by standard Sodium Thiosulphate titrate $(0.025 \mathrm{~N} \mathrm{Na} 2 \mathrm{~S} 2 \mathrm{O} 3)$ using starch as an indicator. The DO was calculated using the following formula (DuttaMunshi and DuttaMunshi, 1995):

$$
\text { DO (mgl-1) }=\text { - } 8 \text { X } 1000 \text { X N }
$$

Where, $\mathrm{V}=$ Volume of sample

$\mathrm{v}=$ Volume of the titrant

$\mathrm{N}=$ normality of the titrant

\subsection{Estimation of Free Carbon-dioxide $\left(\mathrm{FCO}_{2}\right)$ :}

The fate of $\mathrm{CO} 2$ in water is that, when $\mathrm{CO} 2$ enters pure water, a small proportion of it is hydrated to form carbonic acid. Some of the carbonic acid dissociates into bicarbonates and hydrogen ions, bringing about a lowering of the $\mathrm{pH}$. The reactions are as follows:

$$
\begin{aligned}
& \mathrm{CO} 2+\mathrm{H} 2 \mathrm{O}=\mathrm{H} 2 \mathrm{CO} 3 \\
& \mathrm{H} 2 \mathrm{CO} 3=\mathrm{HCO} 3-+\mathrm{H}+
\end{aligned}
$$

Chemical analysis was done on the spot, as there is no any suitable method for FCO2 fixation like dissolved oxygen. $100 \mathrm{ml}$ of sample water was taken in a conical flask. Two drops of Phenolphthalein indicator were added in the above flask. If the solution was colourless, it was titrated with $0.05 \mathrm{~N} \mathrm{NaOH}$ solution. End point was slight pink colour (Trivedi and Goel, 1986; APHA, 1989). The calculation was done as follows:

$$
\text { Free CO2 (mgl-1) }=\frac{(\mathrm{ml} \mathrm{X} \mathrm{N}) \text { of titrant X } 1000 \text { X } 44}{\text { ml. of sample }}
$$

\subsection{Estimation of Total Alkalinity (TA):}

Alkalinity measures the buffering capacity of water. It was estimated by titrating the sample with a strong acid (HCL) using Phenolphthalein and Methyl orange indicators. 100 $\mathrm{ml}$ of sample water was taken in a conical flask. Two drops of Phenolphthalein indicator were added to it. If pink colour appeared, then it was titrated against $0.1 \mathrm{~N}$ HCL to a colourless end point. Now, two drops of Methyl orange indicator were added in the above flask till the end point changed to orange. The total amount of titrant gives the value of titrant for total alkalinity. The total alkalinity as $\mathrm{CaCo} 3$ was calculated by following formula:
Total alkalinity as $\mathrm{CaCO} 3 \mathrm{mgl}-1=$

(ml X N ) of titrant X 1000 X 50

$\mathrm{ml}$ of sample

\subsection{Total Hardness (TH):}

The estimation of total hardness is based on the fact that Eriochrome black ' $\mathrm{T}$ ' forms wine red complex compound with metal ions $(\mathrm{Ca}++$ and $\mathrm{Mg}++)$. The EDTA has got stronger affinity towards $\mathrm{Ca}++$ and $\mathrm{Mg}++$. When the above solution is titrated by EDTA, the former complex is broken down and new complex of blue colour is formed (Trivedi and Goel, 1986; DuttaMunshi and DuttaMunshi, 1995). Waters are often categorised according to degrees of hardness as given in table 3.2 (Durfor and Beeker, 1964)

\section{Categories of water according to degrees of hardness}

\begin{tabular}{|l|l|}
\hline $0-60 \mathrm{mg} \mathrm{l}^{-1}$ & Soft \\
\hline $61-120 \mathrm{mg} \mathrm{l}^{-1}$ & Moderately hard \\
\hline $121-180 \mathrm{mg} \mathrm{l}^{-1}$ & Hard \\
\hline Over $180 \mathrm{mg} \mathrm{l}^{-1}$ & Very hard \\
\hline
\end{tabular}

$100 \mathrm{ml}$ of sample water was taken in a conical flask. To it, $1 \mathrm{ml}$ of ammonia buffer and 5 drops of indicator solution were added. The solution turned wine red in colour. The above solution was titrated by EDTA solution until clear blue colour appeared. The calculation of total hardness was done using the following formula:

Total hardness as $\mathrm{CaCO} 3(\mathrm{mgl}-1)=$

$(\mathrm{ml} \mathrm{X} \mathrm{N})$ of titrant X 1000

\begin{tabular}{|c|c|c|c|c|c|c|c|}
\hline Year & Month & $\begin{array}{l}\text { Water } \\
\text { Temp. }\left({ }^{\circ} \mathrm{C}\right)\end{array}$ & $\mathrm{pH}$ & $\mathrm{DO}$ & $\mathrm{CO}_{2}$ & TA & $\mathrm{TH}$ \\
\hline \multirow{4}{*}{2013} & Sep & $21.6-23.5$ & $\begin{array}{l}6.6- \\
7.2 \\
\end{array}$ & $\begin{array}{l}5.0- \\
6.7 \\
\end{array}$ & $\begin{array}{l}5.3- \\
7.2 \\
\end{array}$ & $\begin{array}{l}56- \\
87 \\
\end{array}$ & $\begin{array}{l}51- \\
69 \\
\end{array}$ \\
\hline & Oct & $18.2-21.1$ & $\begin{array}{l}6.5- \\
6.8\end{array}$ & $\begin{array}{l}5.5- \\
6.7\end{array}$ & $\begin{array}{l}5.3- \\
5.9\end{array}$ & $\begin{array}{l}61- \\
83\end{array}$ & $\begin{array}{l}70- \\
80\end{array}$ \\
\hline & Nov & $13.3-16.3$ & $\begin{array}{l}6.6- \\
7.0\end{array}$ & $\begin{array}{l}5.2- \\
6.1\end{array}$ & $\begin{array}{l}7.1- \\
8.9\end{array}$ & $\begin{array}{l}70- \\
81\end{array}$ & $\begin{array}{l}62- \\
83\end{array}$ \\
\hline & Dec & 9.5-11.1 & $\begin{array}{l}6.6- \\
6.9\end{array}$ & $\begin{array}{l}5.2- \\
6.0\end{array}$ & $\begin{array}{l}8.1- \\
10.2\end{array}$ & $\begin{array}{l}76- \\
107\end{array}$ & $\begin{array}{l}87- \\
99\end{array}$ \\
\hline \multirow{5}{*}{2014} & Jan & $10.0-11.8$ & $\begin{array}{l}6.3- \\
7.0\end{array}$ & $\begin{array}{l}4.6- \\
6.2 .\end{array}$ & $\begin{array}{l}7.8- \\
11.2\end{array}$ & $\begin{array}{l}87- \\
96\end{array}$ & $\begin{array}{l}88- \\
99\end{array}$ \\
\hline & Feb & $13.2-15.2$ & $\begin{array}{l}6.7- \\
7.1\end{array}$ & $\begin{array}{l}4.7- \\
5.6\end{array}$ & $\begin{array}{l}5.3- \\
8.1\end{array}$ & $\begin{array}{l}62- \\
96\end{array}$ & $\begin{array}{l}56- \\
78\end{array}$ \\
\hline & Mar & $15.6-18.8$ & $\begin{array}{l}6.8- \\
7.4\end{array}$ & $\begin{array}{l}5.2- \\
6.5\end{array}$ & $\begin{array}{l}3.4- \\
4.9\end{array}$ & $\begin{array}{l}93- \\
117\end{array}$ & $\begin{array}{l}65- \\
83\end{array}$ \\
\hline & Apr & $21.6-25.2$ & $\begin{array}{l}6.9- \\
8.1\end{array}$ & $\begin{array}{l}6.1- \\
7.4\end{array}$ & $\begin{array}{l}\text { 1.2- } \\
3.4\end{array}$ & $\begin{array}{l}87- \\
139\end{array}$ & $\begin{array}{l}46- \\
49\end{array}$ \\
\hline & May & $21.3-24.2$ & $7.1-$ & 6.4- & $2.3-$ & 89- & 48- \\
\hline
\end{tabular}

ml. of sample

\section{RESULTS \& DISCUSSION:}

Physico-chemical parameter during the study period 


\begin{tabular}{|l|l|l|l|l|l|l|l|}
\hline & & 7.7 & 8.1 & 4.3 & 117 & 78 \\
\cline { 2 - 8 } \multirow{2}{*}{ Jun } & $27.9-30.6$ & $6.9-$ & $6.6-$ & $4.5-$ & $54-$ & $32-$ \\
& & 7.5 & 8.2 & 6.1 & 68 & 41 \\
\cline { 2 - 8 } \multirow{2}{*}{ July } & $28.7-31.6$ & $6.9-$ & $7.3-$ & $5.5-$ & $53-$ & $47-$ \\
& & 7.4 & 8.1 & 7.1 & 68 & 65 \\
\hline \multirow{2}{*}{ Aug } & $26.8-32.2$ & $6.7-$ & $6.9-$ & $4.7-$ & $56-$ & $48-$ \\
& & 7.1 & 7.4 & 8.7 & 61 & 66 \\
\hline
\end{tabular}

\subsection{Total Alkalinity (as $\left.\mathrm{CaCO}_{3}\right)$ :}

Total alkalinity values were found between the ranges of 53 $\mathrm{mg} \mathrm{l}^{-1}$ and $139 \mathrm{mg} \mathrm{l}^{-1}$, highest being in monsoon and lowest in retreating monsoon seasons. According to Boyd (1998), the desired concentration range for bicarbonate $\left(\mathrm{HCO}_{3}^{-}\right)$ alkalinity in pond water is between $50 \mathrm{mg} \mathrm{l}^{-1}$ and $300 \mathrm{mg} \mathrm{l}^{-1}$. Therefore, the present studies indicated that the pond water quality was suitable in terms of alkalinity property for aquaculture practices.

\subsection{Water Temperature $\left({ }^{0} \mathrm{C}\right)$ :}

Temperature is a factor of great importance for aquatic ecosystem, as it affects the organisms, as well as the physical and chemical characteristics of water (Delince, 1992). The temperature of the pond was observed between the ranges of $9.5^{\circ} \mathrm{C}$ to $32.2^{\circ} \mathrm{C}$. Less breeding success occurs when it experiences late monsoon and rainfall. Also, at lower temperature during winter some fishes need specific shelter to escape from light and cold. One such ornamental variety is Botia dario (observation during experiment: bamboo pieces are used inside the aquaria to provide shelter to Botia sp.).

\subsection{Hydrogen Ion Concentration (pH):}

In the above annual cycle, $\mathrm{pH}$ values of pond water were estimated between 6.3 and 8.1 Lowest mean $\mathrm{pH}$ value was observed in winter and highest in pre-monsoon season. According to Banerjea (1971), water with an almost neutral reaction with $\mathrm{pH} 6.5$ to 7.5 is best suited for a fish pond and average production is expected in the range of 7.5 to 8.5 . Present studies indicated that the water of most of the pond was on almost alkaline side (6.9 to 8.1) during the investigation period. The water with $\mathrm{pH}$ of 3.6 to 5.4 has been reported to exert toxic effect on a range of fishes including mortality, reduced growth and poor reproduction (Wilkinson, 2002). The whereas medium water neither strong nor alkaline supported their growth (Sing, 1980 and Pahwa and Malhotra, 1996). Ellis (1937) observed that $\mathrm{pH}$ range of 6.7 to 8.4 is suitable for growth of aquatic biota. All aquatic organisms have a certain tolerance range of $\mathrm{pH}$ value. Fish survive and grow best in waters with a $\mathrm{pH}$ between 6 and 9 .

\subsection{DissolvedOxygen (DO):}

According to Buttneret al. (1993), dissolved oxygen (DO) in a culture system must be maintained above the levels considered stressful to fish. DO value in the present study was observed between the ranges of $4.6 \mathrm{mg} \mathrm{l}^{-1}$ and $8.2 \mathrm{mg} \mathrm{l}^{-}$ 1 , maximum being observed in retreating monsoon and minimum in winter. In the tanks the oxygen level was always above $7 \mathrm{mg} \mathrm{l}^{-1}$ due to regular functioning of air pump and water pump.

\subsection{Free Carbon dioxide $\left(\mathrm{FCO}_{2}\right)$ :}

Free $\mathrm{CO}_{2}$ values were observed between $1.2 \mathrm{mg}^{-1}$ and 11.2 $\mathrm{mg} \mathrm{l}^{-1}$ of which, maximum was observed in winter and minimum in monsoon seasons. According to Saha (1996), the acceptable standard of water $\mathrm{FCO}_{2}$ is between the ranges of $1.5 \mathrm{mg} \mathrm{l}^{-1}$ and $15.0 \mathrm{mg} \mathrm{l}^{-1}$. It has been observed that the mean $\mathrm{FCO}_{2}$ values in all seasons were having same trend of fluctuation. However, the $\mathrm{FCO}_{2}$ level of the pond water was almost suitable for culture of fish in the pond.

\subsection{Total Hardness (TH):}

During the period of investigation, total hardness values of the pond water fluctuated between $32 \mathrm{mg} \mathrm{l}^{-1}$ and $99 \mathrm{mg} \mathrm{l}^{-1}$ throughout the annual cycle (Table:4.1). It was observed maximum in winter and minimum in the retreating monsoon seasons. Normally, the preferred range of hardness for fish culture is less than $50 \mathrm{mg} \mathrm{l}^{-1}$ but, when it is estimated as calcium carbonate; the range should be less than $100 \mathrm{mg}^{-1}$ (Boyd and Tucker, 1998). The total hardness of the pond water during investigation period was soft to moderately hard. The water that is higher in hardness can help to promote the normal growth of fish bone, build up fishes, digestion and absorption of food and stimulate the growth and reproduction of phytoplankton. It indicates that the pond water was mostly productive and acceptable for fish culture.

\section{CONCLUSION}

Physico-chemical parameters play a significant role in the maintenance of a healthy aquatic environment and production of natural food organisms (Rahmanet al., 2009). Day length also has impact on growth of fishes and color variation of ornamental varieties. Less day-length leads to brighter color but more growth and vice versa. Therefore, water quality management and monitoring of other abiotic factors influencing on it; is an important task in aquaculture practice.

\section{ACKNOWLEDGEMENTS}

We want to offer special thanks to Mr. Jujusman Datta (Fish Trader) for sharing with us his colloquial as well as experimental knowledge on various fish species \& behavior. Also we are grateful to all other supportive people we get on the way.

\section{REFERENCES}

[1] DuttaMunshi, J. and DuttaMunshi, J.S. 1995.Fundamentals of Freshwater Biology.Narendra Publishing House.1stedi.

[2] Rahman, A., Yeasmine, S. and Khan, M.M. 2008. Growth Survival and Production of a threatened siluried catfish, Ompokpabda (Hamilton) Fingerlings in nursery ponds.Malays. Appl. Biol, 37 (1):47-56.

[3] Banerjea, S. M. 1971. Water quality and soil condition of fish ponds in some states of India in relation to fish production.Indian J. Fish., 14: 115144. 
[4] APHA, 1989.Standard methods for examination of water and waste water.17thedi. American Public Health Association, Washington, D. C.

[5] Trivedi, R. K. and Goel, P. K. 1986.Chemical and biological method for water pollution studies.Environ. Publ. Karad, India

[6] Durfor, C. N. and Becker, E. 1964. Public water supplies of the 100 largest cities in the United States, US Geog. Sur. Water Supply Paper 1812: 364

[7] Delince, G. 1992. The ecology of the fish pond ecosystem with special references to Africa. Text Book, Kluwer AcademicPublishers.230 pp.

[8] Ellis, M. M. 1937.Direction and measurement of stream pollution. U. S. Fish Bull. No. 45.

[9] Pahwa, D. V. and Malhotra, S.N. 1996.Observation on fluctuation in the abundance of plankton in relation to certain hydrological condition of river Ganga. Proc. Nat. Acad. Sci. India, 60 (B): 237-243.

[10] Singh, K. P. and Samuel, P. 1981. Food, feeding habits and gut contents of Anabas testudineus(Bloch).Matsya., 7: 96-97.

[11] Wilkinson,S. 2002.The use of lime, gypsum, alum and potassium permanganate in water quality management.Aquaculture Asia, VII (2): 12-15.

[12] Saha, R. K. 1996.Some aspects of soil and water quality dynamics in aqua farming.Tri.Fish.Sov., pp. 52-60.

[13] Buttner, J. K., Soderberg, R. W. and Terlizzi, D. E. 1993. An Introduction to Water Chemistry in Freshwater Aquaculture.NRAC Fact.Sheet No. 170. 4 pp.

[14] Boyd, C. E. 1998.Water quality for pond aquaculture.Research and Development Series No. 43. International Center for Aquaculture and Aquatic Environments, Alabama Agricultural Experiment Station, Auburn University, Alabama.

[15] Boyd, C.E. and Tucker, C.S. 1998.Pond Aquaculture Water Quality Management. Kluwer Academic Publisher, London.

[16] Rahman, M.A., Zaher, M. and Azimuddin K.M. 2009.Development of fingerling production techniques in nursery ponds for the critically endangered Reba carp, Cirrhinusariza (Hamilton, 1807).Turk.J. Fish. Aquat. Sci., 9: 165-172. 